Revista Eletrônica Geografar, Curitiba, v. 2, Resumos do VI Seminário Interno de Pós-Graduação em Geografia, p. 22-22. Junho/2007

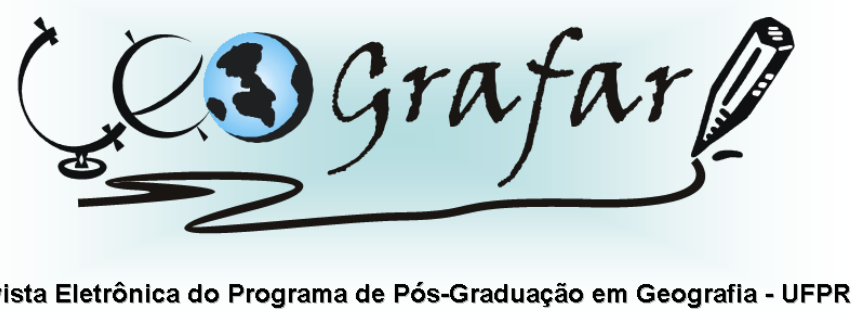

\title{
ANÁLISE DOS PROCESSOS EROSIVOS EM ENCOSTAS COMO SUBSÍDIO AO PLANEJAMENTO E MANEJO DE TRILHAS.
}

\section{EDNILSON FEOLA ${ }^{1}$}

Este trabalho focaliza mudanças na dinâmica da paisagem, induzidas pela atividade turística, em uma encosta montanhosa, na Serra do Mar paranaense, no Parque Estadual do Pico do Marumbi. A pesquisa volta-se ao problema da constatação de processos erosivos, ocasionados pelo trânsito de pedestres em trilhas, como subsídio à implantação de políticas de planejamento e manejo em trilhas em Unidades de Conservação. O problema em foco salienta duas questões: A primeira, - como ocorre e qual é a dinâmica dos processos erosivos atuantes em uma encosta florestada cortada por um sistema de trilhas? A segunda - qual é a relação da interação do uso frente ao incremento dos processos erosivos em trilhas, e quais são as medidas para mitigar tais processos, associados ao planejamento e manejo? - Considerando que o modelo de planejamento e manejo, deveria dar atenção especial ao sistema de trilhas, visando principalmente o controle dos processos erosivos mais atuantes e o seu monitoramento por parte do órgão ambiental responsável. Para isso, será construída uma estação experimental, com duas unidades de monitoramento, que contará com o levantamento do runoff, da capacidade de infiltração do solo, da pluviosidade, da análise física do solo, da erosão por splash, e uso de pinos de erosão. Sendo uma unidade sob cobertura vegetal da área, sem influência da trilha e outra em um segmento de trilha. A observação ocorrerá entre julho de 2007 a março de 2008. A compreensão dos elementos da paisagem na relação com a dinâmica dos processos físicos atuantes na encosta considerados, deverá favorecer o aprimoramento e desenvolvimento de novas técnicas, que auxiliem na orientação da manutenção do equilíbrio desta porção do relevo.

Palavras-chave: Dinâmica da Paisagem; Trilhas; Serra do Mar

${ }^{1}$ Mestrando em Geografia - UFPR - email: Canidia_feola@yahoo.com.br Orientador: EVERTON PASSOS 